\title{
SEMANTIC MODELLING AND ONTOLOGY INTEGRATION OF THE OPEN GOVERNMENT SYSTEMS
}

\author{
Darko Petrušić, Milan Segedinac, Zora Konjović
}

Original scientific paper Open Government Ontology proposed in this paper is an extensive ontology aimed at modelling a wide range of Open Government services. Semantic model of the Open Government opens possibilities for the integration with other semantic and information models, and enables semantic reasoning and resource discovery. Characteristics of the Open Government are transparency, participation and collaboration. Main components of the Open Government are Open Architecture, Open Data and Open Standards. Organizational structure of the Open Government consists of the internal government organizations, associated domains and Open (e)Government services. Open Government Ontology can be used as a semantic meta-data repository for the (e)Government and Open (e)Government services. Using formal methods of reasoning with the proposed ontology we can search for information about Open (e)Government services and infer on gathered knowledge. Also Open Architecture Ontology can be used as Information Architecture framework for the creation of these services as was the case regarding Montenegrin Semantic Science Network.

Keywords: e-Government; ontology; Open Architecture; Open Government; Semantic Web

Semantičko modeliranje i ontološka integracija sustava otvorene vlade

Izvorni znanstveni članak

Ontologija otvorene vlade predstavljena u ovom radu je sveobuhvatna ontologija koja za cilj ima modeliranje šrrokog opsega servisa otvorene vlade. Semantički model otvorene vlade daje mogućnost za integraciju s drugim semantičkim i informatičkim modelima te omogućuje semantičko razmišljanje i pronalaženje resursa. Karakteristike otvorene vlade su transparentnost, sudjelovanje i suradnja. Glavne komponente otvorene vlade su otvorena arhitektura, otvoreni podaci i otvoreni standardi. Organizacijska struktura otvorene vlade sastoji se od unutarnjih vladinih organizacija, povezanih područja i otvorenih (e)vladinih servisa. Ontologija otvorene vlade se može koristiti kao semantičko spremište meta podataka za (e)vladine i otvorene (e)vladine servise. Primjenom formalnih metoda razmišljanja predložena ontologija omogućuje pronalaženje informacija o servisima otvorene (e)vlade i zaključivanje na osnovu prikupljenog znanja. Također, ontologija otvorene arhitekture se može koristiti kao informacijska arhitektura za stvaranje tih servisa, kao u slučaju Crnogorske semantičke naučne mreže.

Ključne riječi: e-vlada; ontologija; otvorena arhitektura; otvorena vlada; semantička mreža

\section{Introduction}

With introduction of Semantic Web [1], new standards for ontologies are developed for machine understandable representation of the Semantic (Web) services, thus enabling the finding of relevant information as well as an intelligent discovery, composition, invocation, monitoring and maintenance of (Web) services on the internet [2]. Current trends in eGovernment development are shift from e- to weGovernment paradigm with the use of Web 2.0 and Web 3.0 technologies. Web 3.0 via Semantic Web Technologies and Linked Data, is being actively promoted and adopted at a Government level, primarily in the context of Open Data. Ontologies are essential in the Semantic Web as they state an agreement to use the vocabulary about a certain domain in a coherent and consistent manner. Ontologies expressed in OWL allow data to be aggregated across the Web. By having foundation ontologies of Open Government we enable a web of government data.

\section{Open Government and Semantic Technologies}

Open Government ideas were born during European humanism movement. Nordic countries were first to adopt Open Government concept and the first one was Sweden (Freedom of the Press Act) in 1766 and Finland (Act on the Openness of Public Documents) in 1951 and then USA in 1966 (Freedom of Information Act) that used as inspiration for the European countries who passed equivalent laws in 1970 (France and The Netherlands in 1978), Australia, Canada and New Zealand in 1982, Hungary in 1992, Ireland and Thailand in 1997, South Korea in 1998, the United Kingdom in 2000, Japan and Mexico in 2002, India and Germany in 2005 [3]. Since then this idea evolved and with development of Internet technologies Open (e)Government gained popularity because of the increased use of electronic services, in general. Open (e)Government can be defined in a number of ways but the OECD definition is probably the most comprehensive one: "Open Government means a Government open to the contribution of Citizens and society to co-create public value and engaged to respect three main principles: ensure full Transparency of its actions, its processes and its data, enable Participation of Citizens to its decisions and processes, promote and accept the Collaboration of Citizens to the production of its services" [4]. Governments today are in development phase of 'Government 2.0', which is providing citizenoriented services enabled by modern features of information and communication technologies [5]. However the future governments are expected to advance toward 'Government 3.0' that is customized and intelligent government using Semantic Web technology and some of its features are used even today.

\section{Related research}

The Open (e)Government initiative depends on the exchange of reusable information and knowledge in the environments that often lack interoperability and this is 
where ontology can produce the best results [6]. The semantically driven e-Government and Open Data are the key initiatives enabling wide adoption of Open (e)Government ontologies and they are supported by many governments participating in the Open Government Partnership [7] launched in 2011. Open Government Partnership is a multilateral initiative with the aim in increase of transparency and accountability of the public sector, as well as in promotion of use of the new technologies in order to strengthen governance.

First Open Data website, aimed to improve access to data in machine-readable format, was launched in May 2009, in the USA [8]. Open Data initiative is actively promoted in the United Kingdom, and its open data portal [9] was launched in January 2010. Since then Open Data initiatives are accepted and implemented by many governments, municipalities and cities.

Many of the important e-Government semantic assets could be found at the collaborative platform, JOINUP portal, created by the European Commission. Some of the successful examples of Open (e)Government / eGovernment ontologies are [10]: oeGOV, CGOV, OntoGov, SemanticGov, OCD, OGPA and TerraGov.

The aim of the oeGOV project (Ontologies for eGovernment) [11] is to enrich the US Open Data, published through the portal DATA.gov with the semantic descriptions [12]. TheoeGOV project is limited to developing ontology for the specific interest area, i.e. to enable interoperability between different U.S. Government organizational units. In the UK, the Central Government Ontology (CGOV) is created within the data.gov.uk initiative, as well as Parliament Ontology (PARL). In similar way "Ontologiadella Camera deiDeputati" (OCD) that describes the organization of the Chamber of Deputies in the Italian Republic [13] has been developed. These ontologies are relying on the FOAF (Friend of a Friend) ontology to model people, activities and relationships. However some successful implementations of eGovernment ontologies are document-centric such as the Ontology of Greek Public Administration [14].

OntoGov (The e-Government services factory) [15] project is based on the Semantic Web services, business modeling, and SOA principles [16]. The OntoGov approach focuses mainly on the software engineering side and it is quite complex to use and maintain.

TerraGov (Impact of eGovernment on Local Government Services) [17] is the EU project that provides ontology as well as a SOA-based platform for the enhancement of the existing government web services with semantic descriptions [10]. Focus of the project is solely on the requirements of governments at local and regional levels [18].

Another European project is SemanticGov (Providing Integrated Public Services to Citizens at the National and Pan-European level with the use of Emerging Semantic Web Technologies) [19] and it is aimed to prepare the ground for the administrative dimension of the European unification ("Common European Administrative Space") by resolving the incompatibilities between the particular public authorities [10].

It appears that none of those ontologies are offering generic ontological framework, and in many cases they are created with the aim to satisfy specific requirements and demands. Therefore, there is a need for the generic solution i.e. for the Open (e)Government domain ontology that also has capabilities to integrate existing specific government ontologies and corresponding architectures. Furthermore, the Open (e)Government domain ontology could be used as a tool for the knowledge acquisition within governments [20].

\section{Open Government Ontology}

Open Government Ontology proposed in this paper is an extensive domain Ontology aimed at modelling and integrating a wide range of Open Government services and information. Semantic model of the Open Government opens possibilities for the integration with other semantic and information models, and enables semantic reasoning and resource discovery [21]. Fig. 1 shows the graphical view of the Open Government Ontology including Open Government characteristics, components and organizational structure. Open Government should enable transparency, participation and collaboration and main components of the Open government are Open Architecture component, Open Data component and Open Standards component. Organizational structure of the Open Government consists of the internal government organizations, associated domains and Open Government services.

\subsection{Open Government characteristics 4.1.1 Transparency}

Transparency is one of the key characteristics of the Open Government initiative and it means that information collected by Government's institutions should be available to the public, with limited exceptions, in a timely manner, in open data formats and with possibility of reuse [22].

\subsubsection{Participation}

The introduction of the Web 2.0, enabling interactive features on Government's online presence, will allow citizens to participate in decision-making, as well as to contribute ideas and information that should shape policies, strategies, and laws that best serve common public interests [22].

\subsubsection{Collaboration}

Collaboration and public involvement evolved over time especially in recent years due to rapid development of internet technologies and has become an important enabler of the Open Governement paradigm [3]. Collaborative partnering and public involvement allows the government to expand the expertise and increases the public support on decisions. Collaboration improves the effectiveness of Government by encouraging partnerships and cooperation between the Government and citizens, Government and private institutions and within the Government itself. 


\subsection{Open Government organizational structure 4.2.1 Open Government services}

One of the primary purposes of government is to provide services to meet the needs of its citizens, as well as to provide value to the citizens [22]. The success of Open (e)Government lies in enabling Public Services to become available all the time and to deliver these with a positive impact on the lives of their users. The Open Government Services provides a comprehensive list of the (e)services available as well as applications that are enabling those services.

Certain Open Government organizations provide and administer services that correspond to various domains.

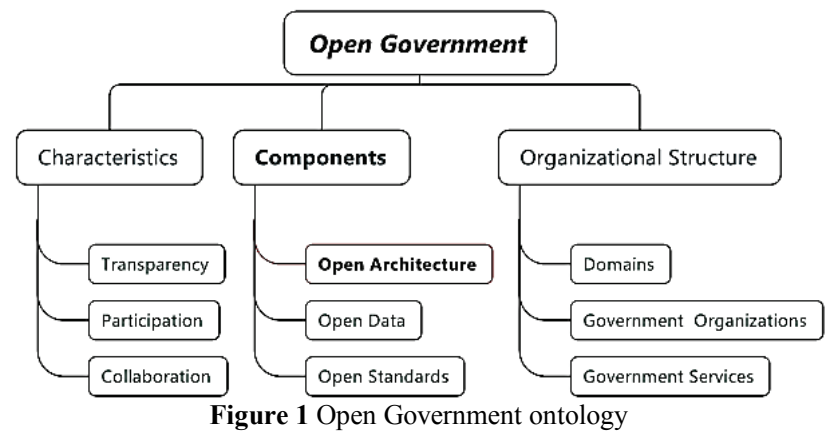

\subsubsection{Domain}

According to [23] the main e-government domains (categories) encompass Art, Culture and History, Civil Status and Rights, Education and Learning, Employment and Business, Environment and Resources, Home and Community, Health and Well Being, Law and Enforcement, Motoring and Transport, Social Benefits and Grants, Taxes and Customs, Travelling and Tourism. We also added Security, Research and Innovation as well as Technology domains. Each domain should contain the number of (e)services available and the domain is also in jurisdiction of one or more Government organizations.

\subsubsection{Government organization}

There are many ways to organize government, but the most common model, described by the Baron de Montesquieu (The Spirit of the Laws, 1748), involves three branches of government: executive, legislative and judicial. Constitutions vary extensively as to the degree of separation of powers between these branches.

\subsection{Open Government components 4.3.1 Open data component}

Open data is the key enabler of the Open government. Other components of the Open government are participating in creation of the Open data. The W3C eGov Interest Group defined open data as publishing data in its raw format, machine-readable for its full reuse in applications developed by others [24]. Data is open if it can be freely used, reused and redistributed by anyone [9]. Vision of Open Government Data (OGD) is to realise significant economic benefits by enabling businesses and non-profit organisations to build innovative applications and websites using public data [25]. The Semantic Web is different because it is not just about putting data on the Web, it is also about making data interconnected, so that a human or machine can explore the web of data. Linked open government data (LOGD) is the combination of machine power and human power that delivers higherquality information and/or data to a wide range of data consumers via advanced applications (visualization, mash-ups, etc.).

\subsubsection{Open standards component}

The Open standards define the measures that different governments must adopt in order to advance and become Open Governments. Government organisations recognize the importance of open standards to promote civil society access to public data, as well as to facilitate the interoperability of government information systems.

Many underlying semantic technologies discussed in this paper are standardized in $\mathrm{W} 3 \mathrm{C}$ as part of the Semantic Web activity. W3C has established the eGovernment Activity and the E-Government Interest Group (eGov IG) [26, 2]. The main goal of the eGov IG is to "explore how to improve access to government through better use of the Web and achieve better government transparency using Open Web standards at any government level (local, state, national and multinational)".

\subsubsection{Open Architecture component}

Within the Open Government Ontology, a lot of development work has been done on Open Architecture, which is Architecture for Open Government [27]. Open Architecture should enable transformation from egovernment and connected government to Open Government. Main purpose of the OA is to facilitate implementation of Open Government by enabling seamless delivery of Open Data and creation of Linked Open Government Data. Each component of the Open Government Ontology can have its own ontology representation and if we further expand $\mathrm{OA}$ component (Fig. 1) we will get detailed breakdown of the OA ontology, which is presented in Fig. 2 [28].

Short descriptions of the classification of the presented model and its components are as follows:

1) Agents are the entities that are providing, using and enhancing the data. Agents can be Data providers and Data consumers.

2) Data is the entity that represents Data source and Data storage in different formats and different level of business maturity.

3) Services are the entities that are transforming and integrating data and they are Integration services, Interactive services, Analytics, Delivery channels and Access points.

4) Influencers are Governance and Enterprise Architecture (EA). EA detailed breakdown is presented in Fig. 3. 


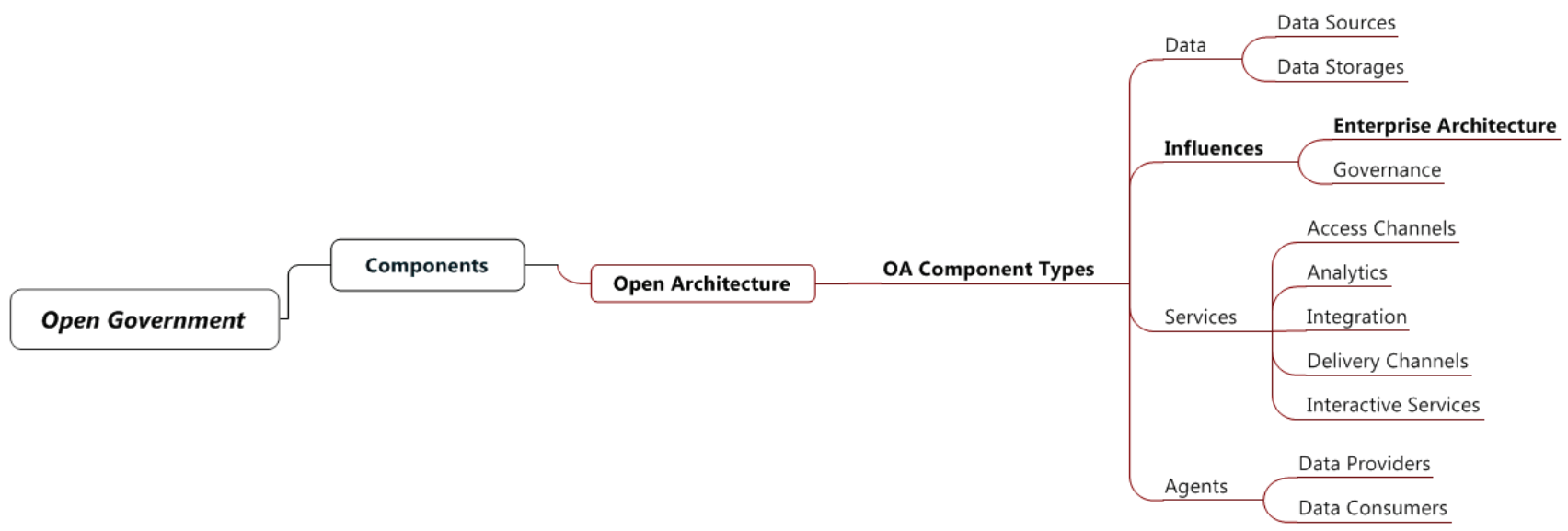

Figure 2 Open Architecture ontology

\section{$5 \quad$ Research information systems}

There are two different kinds of systems dealing with research related information: Social networking tools for researchers and institutional and national research information systems also referred to as Current Research Information Systems (CRIS) [30]. Also there are two different kinds of Open Data, one is Open Government Data (OGD) and another is data generated from scientific and research projects funded through governments grants. Connecting these two different kinds of Open Data is possible by using rich metadata i.e by using CERIF (Common European research Information Format). CERIF (Common European Research Information Format) is a model format to manage Research Information. CERIF was developed with the support of the EC (European Commission) in two major phases: $1987 \div 1990$ and $1997 \div 1999$. It is a standard; technically it is an EU (European Union) Recommendation to member states [29]. The CERIF Full Data Model (FDM) specification document provides information about the CERIF model. With the latest release, the relational model structure is highly normalized and allows the flexibility and scalability in applications by introduction of the so called Semantic Layer (Classification Entities). The strength of CERIF is in the semantic relationships between research entities. Beyond that, CERIF enables communication and data exchange across applications via the CERIF XML data exchange format. CERIF XML has been designed for data exchange at a machine level and therefore corresponds closely with the structure of the CERIF model.

The core CERIF entities are Person, Organisation Unit, Result Publication and Project. The Common European Research Information Format (CERIF) Ontology Specification [29] provides basic concepts and properties for describing research information as semantic data.

\section{Montenegrin Semantic Science Network ontology}

Montenegrin Semantic Science Network $\left(\mathrm{MS}^{2} \mathrm{~N}\right)$ project arose from the need to facilitate and improve electronic communication and collaboration of researchers and the research and scientific institutions both at home and in the diaspora. At the same time there is a need to collect and classify information on national researchers and the research performing organizations. However $\mathrm{MS}^{2} \mathrm{~N}$ is evolving in virtual meeting place for the global scientific community interested in research and scientific activities in Montenegro providing opportunities for scientific collaboration. $\mathrm{MS}^{2} \mathrm{~N}[31]$ is part of Open Government landscape which belongs to CRIS type of system.

Montenegrin Semantic Science Network model is based on the Open Architecture component proposed in this paper, semantic technologies, CERIF standards and Frascati methodology for collecting statistics about research and development. During design phase of $\mathrm{MS}^{2} \mathrm{~N}$ application we decided to use Semantic CMS (Aloha Editor + Apache Stanbol + Drupal $7=$ Semantic CMS) [32] and results of the IKS project as an application base for our $\mathrm{MS}^{2} \mathrm{~N}$ portal development. Interactive Knowledge Stack (IKS) is an Integrating Project [33] that started in January 2009 providing an open source technology platform for semantically enhanced content management systems. CMS Drupal has all the features required to implement open websites up and running quickly (e.g. commenting, blogging, forums, aggregation, data mashup, micro-blogging, voting, etc.) [3]. Also it becomes software tool of choice for enabling transparency, participation, and collaboration between the government and its citizens.

Drupal, as the main component of the Semantic CMS, can be EAV-driven, where EAV stands for Entity Attribute Value. EAV is one of the five possible physical database designs for implementing logical Generalization Hierarchies [34]. These are EAV, EAV hybrid table, Horizontal Disjunctive Partitioning table, Vertical Disjunctive Partitioning table and Null-able Attributes table. EAV is also known as vertical database model, open schema, object-attribute-value model or sparse matrix model [35]. Also Extensible Markup Language (XML) syntax is related to attribute-value pairs [36], and Resource Description Format (RDF) can be represented in $\mathrm{XML}$, where the basic unit of information in RDF is an object-attribute-value triplet. Every EAV system must contain metadata structure and that is a tradeoff for simplicity in the physical and logical structure of the data. Well-known information systems using EAV design are clinical data repositories (CDRs), since EAV design addresses a problem that conventional table design cannot 
resolve i.e. data on several thousand parameters that can change over time, stored for a patient across all clinical specialties. And the first use of EAV design for CDR dates back to the TMR (The Medical Record) system in the late 1970s, and the HELP system with its commercial version $3 \mathrm{M}$ CDR. This model was later upgraded to Columbia-Presbyterian Medical Center (CPMC) CDR. Since then there are many Clinical Study DataManagement Systems (CSDMS) that have been developed by software vendors such as Oracle Corporation, Medidata Solutions, BioClinica and others. The main advantage of the use of EAV database model, in development of non-clinical systems, is in its ability for easy upgrade and development as this model provides more flexibility to play with data and attributes. Since EAV model that we use in $\mathrm{MS}^{2} \mathrm{~N}$ database development is more complex than traditional relational models due to the metadata structure, corresponding ontology mapping of the $\mathrm{MS}^{2} \mathrm{~N}$ database is quite complex. In order to create $\mathrm{MS}^{2} \mathrm{~N}$ database (part of Information Architecture ontology - Fig. 3) we used Data Master plug-in v1.3.2 in Protégé 3.4.2. allowing the user to import, in a configurable way, a relational database (MySQL) structure into Protégé-OWL ontologies. The database is exported in .sql file which is then used for import process and to build initial version of the ontology.

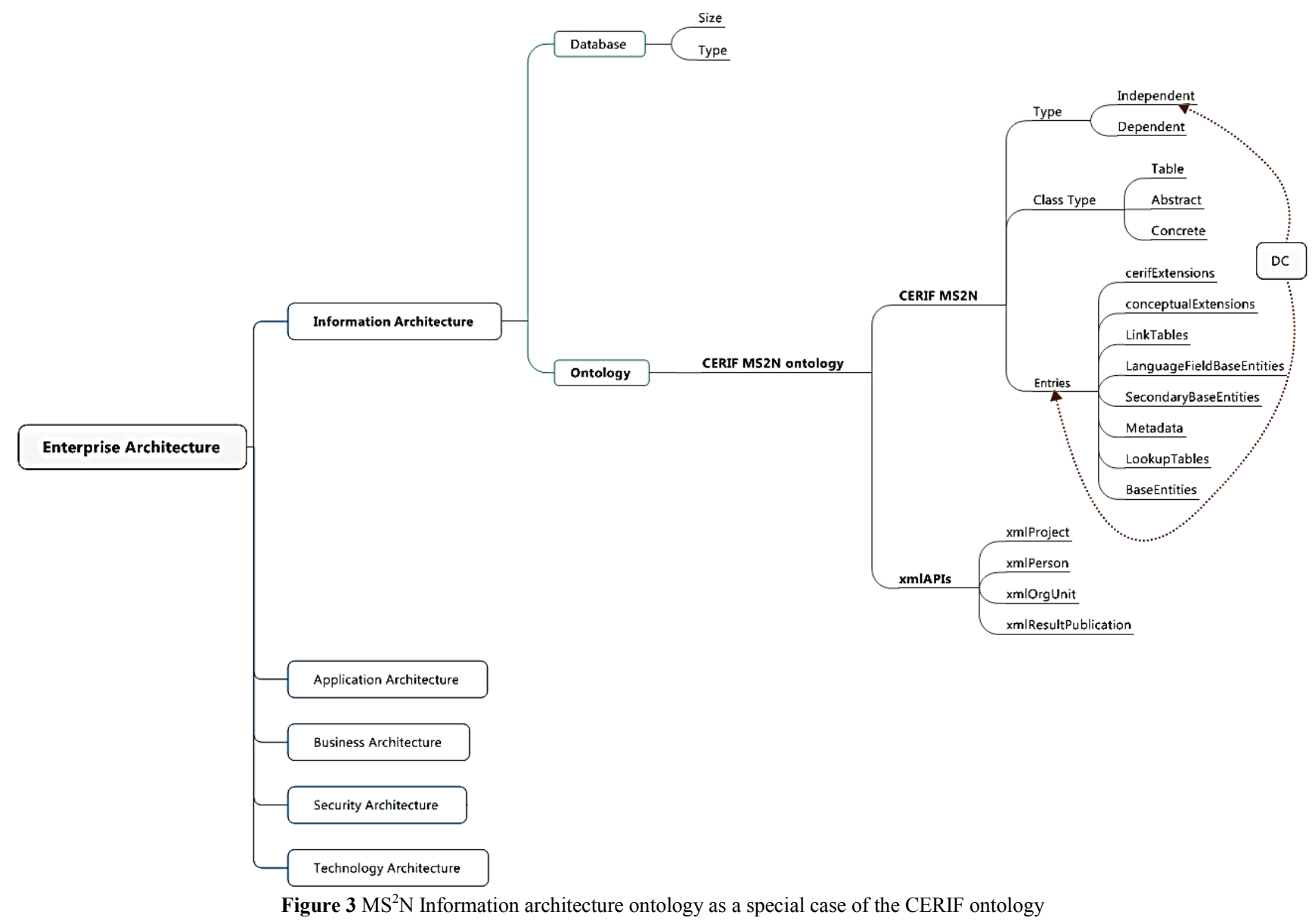

Since $\mathrm{MS}^{2} \mathrm{~N}$ database ontology structure corresponds to EAV database model and it is created by direct upload of the structure of the $\mathrm{MS}^{2} \mathrm{~N}$ database there was a need to transform and organize this ontology in accordance with CERIF standards set by euroCRIS organization [29]. CERIF ontology and the new CERIF_MS ${ }^{2} \mathrm{~N}$ ontology are very similar in structure i.e. both ontologies have two super classes containing all the other classes and both ontologies have the same four basic entities that are presented as xmlAPIs. In addition, the internal layout within superclass is the same with one major difference and that is the addition of a class Metadata introduced by CERIF_MS ${ }^{2} \mathrm{~N}$ ontology due to implementation of EAV database model. Metadata class in this form is not present in CERIF ontology because it uses pure relational database model as a base. This also means that the differences between ontologies are present at the end of the ontology hierarchical chain in the entities or classes that are describing the basic entities. The main differences between these two ontologies exist at the level of the socalled SecondaryBase entities or classes that describe the four basic entities (ResultPublication, Person, Project, and OrganisationUnit). Thus these two ontologies are very similar, and the differences have arisen in the part that makes CERIF_MS ${ }^{2} \mathrm{~N}$ unique ontology - namely EAV data model and data structure. Fig. 3 depicts the core of the CERIF_MS ${ }^{2} \mathrm{~N}$ ontology.

Thus far we described Information Architecture ontology of the $\mathrm{MS}^{2} \mathrm{~N}$ information system (IS). Also there is direct correlation between $\mathrm{MS}^{2} \mathrm{~N}$ IS architecture and OA ontology mapping which may be seen in the simplified form presented in Fig. 4. Within Open Government Ontology, $\mathrm{MS}^{2} \mathrm{~N}$ IS is modelled as Research and innovation type of Open (e)Government service and it is under the jurisdiction of the Ministry of Science while its components are defined by the Open Architecture 
Ontology. $\mathrm{MS}^{2} \mathrm{~N}$ service also belongs to Science domains and Technology domain. $\mathrm{MS}^{2} \mathrm{~N}$ service enables transparency, by providing data in non-machine readable formats, active participation via blogs and people to government collaboration by providing possibility to create organic groups. Main stakeholders of the $\mathrm{MS}^{2} \mathrm{~N}$ service that are providing, using and enhancing data are Data providers and Data consumers. Data providers are public sector, universities, NGOs and researchers that are providing data in various formats which are then stored in information systems. Data consumers are citizens and organizations, including Data providers, and they are part of the human power and/or human participation as part of external forces that are providing value-added services and improving quality of the OGD. Data consumers are the end user of the OG applications and OGD/LOGD but these also may be enterprises, citizens, other governments or international agencies.

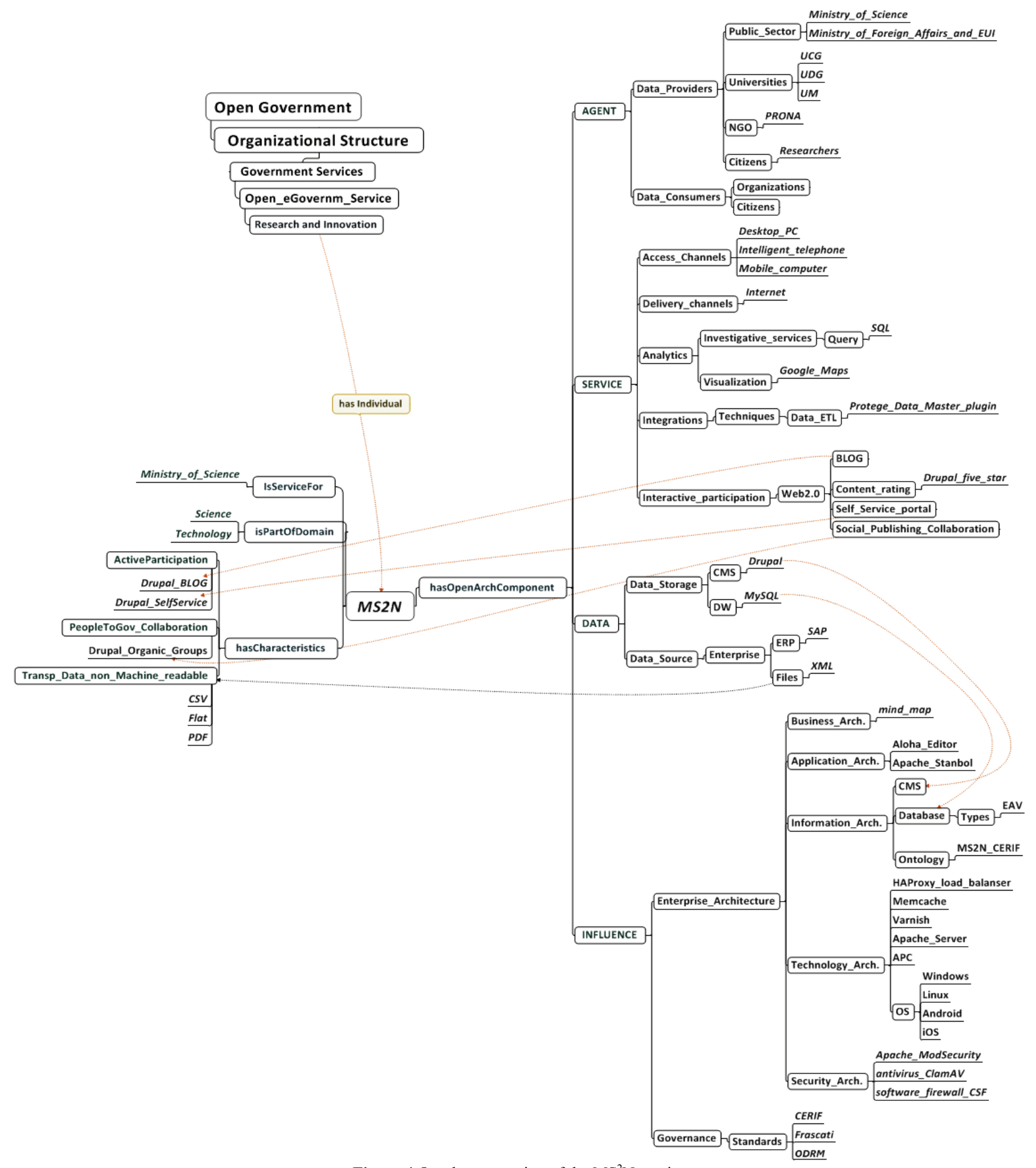

Figure 4 Ontology mapping of the $\mathrm{MS}^{2} \mathrm{~N}$ service

Data sources are entities aimed for keeping data in Data storages, collected by Data providers, in digital form. Data storages are databases with transformed, merged and cleaned data from different Data sources.
This process (data transfer from Data sources to Data storages) is made possible by using Integration services. Integration services are enabling extraction, transformation and loading of data from Data sources into 
Data storages. Once data is in Data storages there is a need to prepare the data for publication by using Analytic services. Analytic service is responsible for creating information from the data that is in Data sources by using visualization and investigative tools and publishing the information via Delivery channels. In order to improve quality of the published information and to promote participation and collaboration we used some of the Web 2.0 features that are enabling Interactive participations such as blogging, micro-blogging, ratings etc.

Delivery channels allow publishing information prepared by the Analytic services and/or raw data from Data source or Data storage. Delivery channels are in essence technology platform such as Internet and Cloud computing that are accessible by Access points. Access points are hardware (and software) that are enabling Delivery channels to be accessible by Data consumers. In addition, there are overarching components that have strong influence on the presented system and they are Governance and Enterprise Architecture. Governance includes area of privacy, policies, IT governance, processes and procedures, and standards. Enterprise Architecture is deeply embedded within OA ontology and plays important part of the OG ontology. EA is comprised from Business, Application, Information, Technology and Security Architecture components. All of the $\mathrm{MS}^{2} \mathrm{~N}$ service components/individuals are defined by Open Architecture ontology and that is in details presented in Tab. 1.

Table 1 OA ontology mapping of the $\mathrm{MS}^{2} \mathrm{~N}$ IS Architecture

\begin{tabular}{|c|c|c|}
\hline \multicolumn{2}{|c|}{ OA ontology components } & Components of the $\mathrm{MS}^{2} \mathrm{~N}$ information system architecture \\
\hline \multirow{2}{*}{ Agent } & \begin{tabular}{l|l|} 
Data \\
Providers \\
\end{tabular} & $\begin{array}{l}\text { Universities, Scientific Institutes, researchers and CRIS systems providing PhD and Master thesis in } \\
\text { different formats, classification and information about researchers and their projects }\end{array}$ \\
\hline & $\begin{array}{l}\text { Data } \\
\text { Consumers }\end{array}$ & Citizens and Organizations \\
\hline \multirow{2}{*}{ Data } & Data source & SAP files and files in non machine readable formats (PDF, CSV, Flat) \\
\hline & Data storage & MySQL database \\
\hline \multirow{5}{*}{ Service } & Integration & DB export/import tools; Protégé plug-in for importing database concepts into ontology; \\
\hline & Analytics & $\begin{array}{l}\text { Visualization (Google Maps); Investigative services (SQL) in conjunction with embedded analytics } \\
\text { services in DRUPAL CMS. }\end{array}$ \\
\hline & $\begin{array}{l}\text { Delivery } \\
\text { Channels } \\
\end{array}$ & $\begin{array}{l}\text { Internet is used together with Web browsers (IE, Firefox, Safari, Crome, Opera) based on Linix Virtual } \\
\text { Machine. }\end{array}$ \\
\hline & $\begin{array}{l}\text { Access } \\
\text { Devices }\end{array}$ & PC's, mobile computers, tablets \\
\hline & $\begin{array}{l}\text { Interactive } \\
\text { services }\end{array}$ & $\begin{array}{l}\text { Researchers can be data providers and data consumers, since they are populating static information and } \\
\text { creating dynamic content of the } \mathrm{MS}^{2} \mathrm{~N} \text { IS such as blogs (Drupal_Blog), rating (Drupal_five_stars) and } \\
\text { using selfservice functionalities (Drupal_Selfservice). } \\
\text { Also portal is place where they collaborate on research activities and projects organized as virtual teams } \\
\text { using social publishing collaboration tools (Drupal_Organic_Groups). }\end{array}$ \\
\hline \multirow[t]{2}{*}{ Influence } & $\begin{array}{l}\text { Enterprise } \\
\text { Architecture }\end{array}$ & $\begin{array}{l}\text { Technology Architecture: Hosting service can be used with Linux CentOS, Apache Server, HAProxy } \\
\text { load balancer and caching systems Memcache, APC and Varnish } \\
\text { Information Architecture: Relational Database Management System MySQL, MS }{ }^{2} \text { N_CERIF ontology, } \\
\text { Drupal (CMS), EAV database model } \\
\text { Application Architecture: Aloha Editor and Apache Stanbol } \\
\text { Security architecture: antivirus ClamAV, software firewall CSF and Apache ModSecurity } \\
\text { Business Architecture: Mind Map }\end{array}$ \\
\hline & Governance & $\begin{array}{l}\text { CERIF (Common European Research Information Format); Frascati methodology for scientific } \\
\text { classification; Open Digital Rights Management (ODRM) Framework }\end{array}$ \\
\hline
\end{tabular}

Therefore Open Architecture ontology is used for the system architecture mapping of the $\mathrm{MS}^{2} \mathrm{~N}$ IS and this may be done for any other Open (e)Government service. Open Government ontology framework may contain information about all Open (e)Government services where their components are completely mapped by Open Architecture ontology. In more generic term, now we can use the Open Government ontology as a semantic metadata repository for the Open(e)Government services [37, 38]. The concept of meta-data was embedded into the core of the Semantic Web and by the use of meta-data it is possible to search for information by content and to infer on gathered knowledge. The role of ontologies in managing the content and knowledge [39] in a practical and reusable way is of critical importance in knowledge centric organizations, such as governments [40]. For the demonstration purposes we have chosen three most important (e)Government services of Ministry of Science and we mapped them using Open Government ontology model. Those services are MoS portal 41], $\mathrm{MS}^{2} \mathrm{~N}$ portal and portal of the Higher Education for Research and Innovation project - HERIC [42].

\section{An example of the model application}

In our example we explored the use of rules to implement conditions related to $\mathrm{OG}$ characteristics (transparency, participation and collaboration) and determine if services $\mathrm{MoS}$ portal, $\mathrm{MS}^{2} \mathrm{~N}$ portal and HERIC portal satisfy requirements for Open (e)Government service using our OG ontology and the Protégé software. For that purpose we used Semantic Web Rule Language (SWRL) [43] and the Protégé plugin software. Protégé provides a knowledge acquisition tool, the SWRL plug-in to Protégé [44] that can use OG ontology, as well as SWRL-based OWL query language called Semantic Query-Enhanced Web Rule Language (SQWRL), which is a SWRL-based language for 
querying OWL ontologies. It provides SQL-like operations to retrieve knowledge from OWL. So, we firstly used SQWRL for querying OG ontology and executed three queries in oder to find out if above mentioned services satisfy requirements for Open (e)Government service. First query (1) provides information which services are satisfying transparency requirement.

Research_and_innovation(?x) $\wedge$ hasComponent(?x, ?a) $\wedge$ hasCharcterisic_OeG_Transparency(?x, ?y) $\wedge$

isEnabled_By(?y, ?a) $\rightarrow$ sqwrl:select(?x, ?a)

The first query returns that all three services $(\mathrm{MoS}$ portal, $\mathrm{MS}^{2} \mathrm{~N}$ portal and HERIC portal) are supporting transparency by presenting data to users in PDF, CSV and flat data format.

Second query (2) will provide us with information which services are satisfying participation requirement.

Research_and_innovation(?x) $\wedge$ hasComponent(?x, ?b) $\wedge$ hasCharcterisic OeG Participation(?x, ?z) isEnabled_By(?z, ?b) $\rightarrow$ sqwrl:select(?x, ?b)

The second query returns that only service $\mathrm{MS}^{2} \mathrm{~N}$ is supporting participation via Drupal_SelfService and Drupal_Blog OA components.
Third query (3) provides information about which services are satisfying collaboration requirement.

Research_and_innovation(?x) ^hasComponent(?x, ?c) $\wedge$ hasCharcterisic_OeG_Collaboration(?x, $\wedge$ isEnabled_By(?e, ?c) $\rightarrow$ sqwrl:select(?x, ?c)

The third query returns that only service $\mathrm{MS}^{2} \mathrm{~N}$ is supporting collaboration via Drupal_Ogranic_Groups OA component.

Accordingly, theMoS portal with its technical and functional configuration is supporting transparency but not participation and/or collaboration features just like the HERIC portal. However, $\mathrm{MS}^{2} \mathrm{~N}$ portal supports transparency, participation and collaboration and satisfies requirements for Open (e)Government service as shown in Fig. 5. Secondly, we used SWRL rules with the Drools rule engine to infer about the same, i.e. if services MoS portal, $\mathrm{MS}^{2} \mathrm{~N}$ portal and HERIC portal satisfy requirements for Open (e)Government service. Drools [45] is a business rule management system with a forward and backward chaining inference based rules engine, using modified version of the Rete algorithm. For this purpose we used Protégé SWRLDrools Tab plug-in.
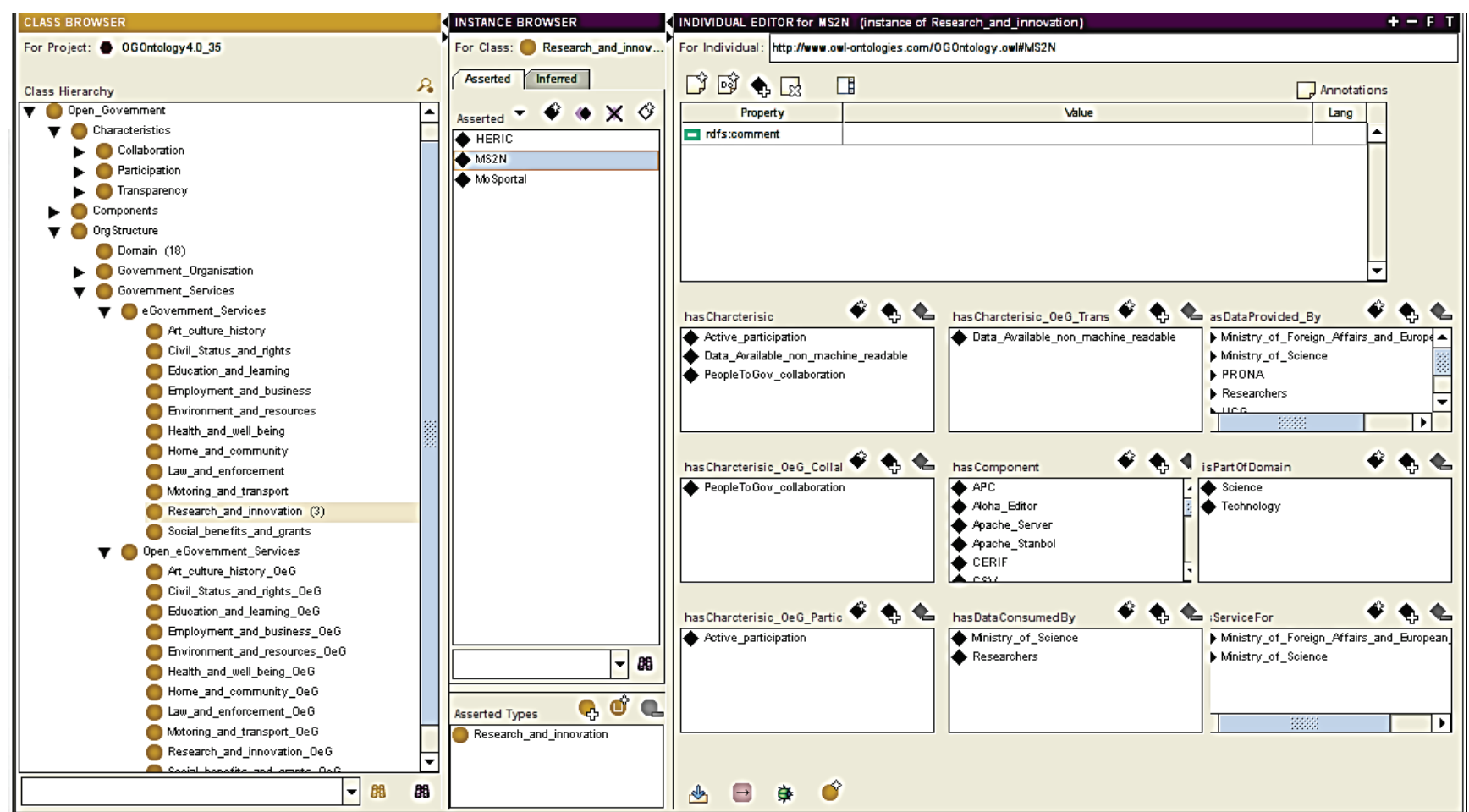

Figure 5 Protégé interface presenting three mapped services within Open Government ontology

SWRL Editor allows transformation of OWL knowledge and SWRL rules into Drools knowledge represented in Drools facts and rules [46]. The SWRLDroolsTab uses an OWL 2 RL-based reasoner. Once the relevant OWL concepts and SWRL rules have been represented in Drools, the Drools execution engine can perform inference. When the inference process is completed, those facts can be transformed into OWL knowledge. The SWRL rule that we used to allow new OWL knowledge to be created, is as follows:

Research_and_innovation(?x) $\wedge$ hasComponent(?x, ?a) $\wedge$ hasComponent(?x, ?b) $\wedge$ hasComponent(?x, ?c) $\wedge$ hasCharcterisic_OeG_Transparency(?x,?y) $\wedge$ isEnabled_By(?y,?a)

hasCharcterisic_OeG_Participation(?x, ?z) 
isEnabled_By(?z, ?b)

$\wedge$ has $\bar{C}$ harcterisic_OeG_Collaboration(?x,?e) $\wedge$ isEnabled_By(?e, ?c) $\rightarrow$

Research_and_innovation_OeG(?x)

Detailed explanation of the rule (4) is presented in Tab. 2 [47], while the new OWL knowledge is visible in
Protégé graphical interface (see Fig. 6), after the above rule was applied to reasoning process.

By comparing Fig. 5 and Fig. 6 we can see that new knowledge is created, i.e. there is a new service mapped $\left(\mathrm{MS}^{2} \mathrm{~N}\right)$ in OG ontology under Open_eGovernment Services (Research_and_Innovation). Therefore $\mathrm{MS}^{2} \mathrm{~N}$ is the only e-service that satisfies transparency, participation and collaboration requirements for Open (e)Government services.

Table 2 SWRL rules for Open e-Government service requirements

\begin{tabular}{|c|c|c|}
\hline Part of the rule & Explanation & Semantics \\
\hline Research_and_innovation(?x) & $\begin{array}{l}\text { IF Research and innovation e-Government } \\
\text { service }\end{array}$ & \\
\hline$\wedge$ & and & \\
\hline $\begin{array}{c}\text { hasComponent(?x, ?a) } \wedge \text { hasComponent(?x, ?b) } \wedge \\
\text { hasComponent }(? \mathrm{x}, ? \mathrm{c})\end{array}$ & service has three components a,b and c & $\begin{array}{l}\text { e-service architecture fits } \\
\text { within OA framework and it } \\
\text { has three components }\end{array}$ \\
\hline$\wedge$ & and & \\
\hline $\begin{array}{c}\text { hasCharcterisic_OeG_Transparency }(? \mathrm{x}, ? \mathrm{y}) \wedge \\
\text { isEnabled_By(?y, ?a) }\end{array}$ & $\begin{array}{l}\text { It has characteristic transparency which is } \\
\text { enabled by component a }\end{array}$ & $\begin{array}{c}\text { where first OA component of } \\
\text { the service is enabling } \\
\text { transparency }\end{array}$ \\
\hline & and & \\
\hline $\begin{array}{c}\text { hasCharcterisic_OeG_Participation }(? \mathrm{x}, ? \mathrm{z}) \wedge \\
\text { isEnabled_By(?z,?b) }\end{array}$ & $\begin{array}{l}\text { It has characteristic participation which is } \\
\text { enabled by component } b\end{array}$ & $\begin{array}{l}\text { second OA component is } \\
\text { enabling participation }\end{array}$ \\
\hline$\Lambda$ & & \\
\hline $\begin{array}{c}\text { hasCharcterisic_OeG_Collaboration(?x, ?e }) \wedge \\
\text { isEnabled_By(?e, ?c) }\end{array}$ & $\begin{array}{l}\text { It has characteristic collaboration which is } \\
\text { enabled by component } \mathrm{c}\end{array}$ & $\begin{array}{l}\text { third OA component is } \\
\text { enabling collaboration }\end{array}$ \\
\hline$\rightarrow$ & THEN & \\
\hline Research_and_innovation_OeG(?x) & $\begin{array}{l}\text { Research and innovation e-Government } \\
\text { service is the Open e-Government service }\end{array}$ & \\
\hline
\end{tabular}

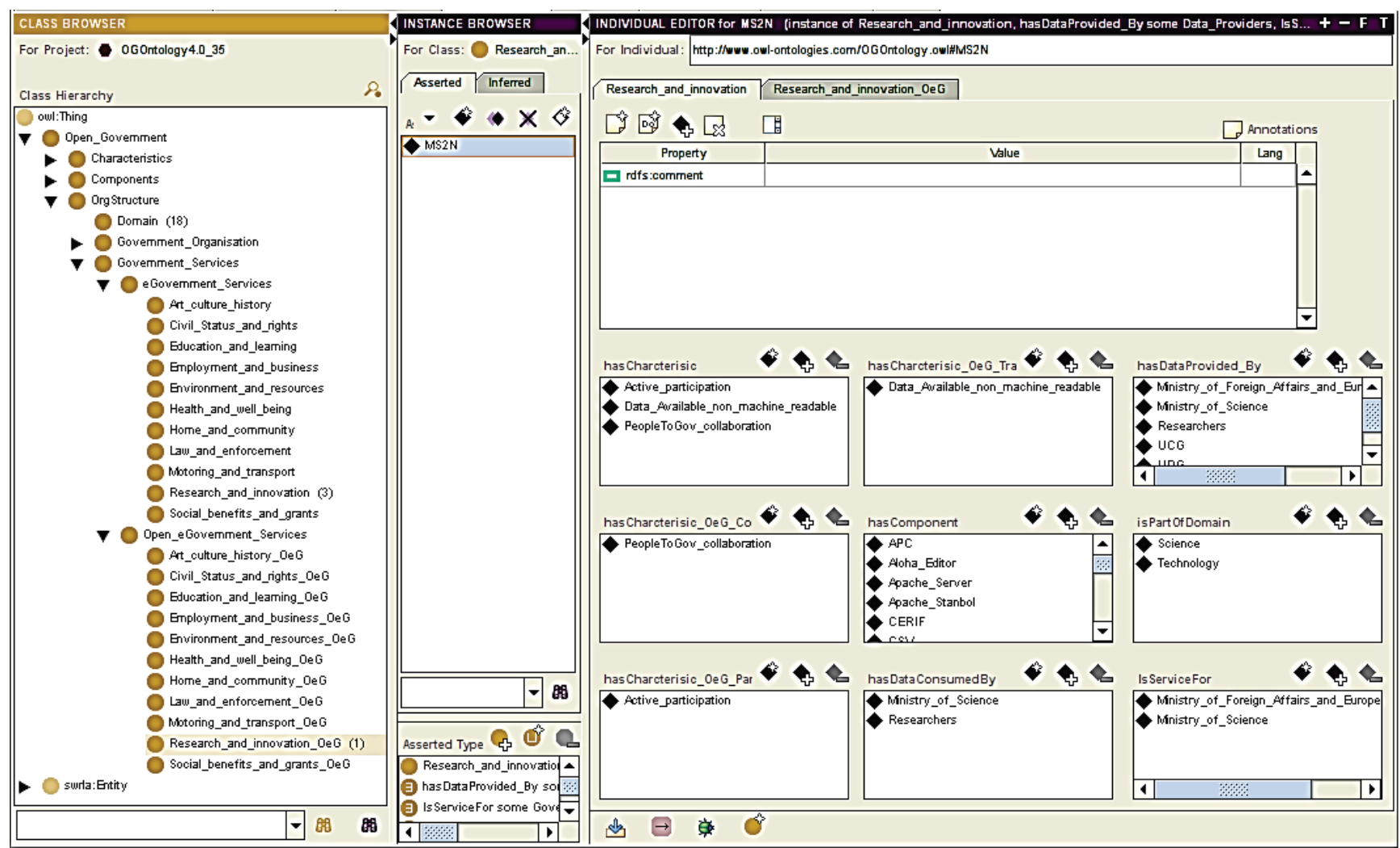

Figure 6 Protégé interface after successful transformation of the new knowledge into Open Government ontology

\section{Conclusion}

Main characteristics of the Open Government are transparency, participation and collaboration and the main components of the Open government are Open
Architecture, Open Data and Open Standards. Open Government ontology, which is proposed in this paper, is an extensive ontology comprising characteristics, components and organizational structure. Within the Open Government ontology a lot of development effort 
has been done on Open Architecture (OA), which is Architecture for Open Government. OA ontology model was created and used as a system architecture mapping for the software development of the $\mathrm{MS}^{2} \mathrm{~N}$ IS. Furthermore $\mathrm{MS}^{2} \mathrm{~N}$ Information Architecture ontology is developed as a special case of the generic CERIF ontology that is used by $\mathrm{MS}^{2} \mathrm{~N}$ IS, and then this ontology is integrated within the Open Government ontology. Open Government ontology framework, within its organisational structure, can contain information about eGovernment and Open (e)Government services, mapped by Open Architecture ontology. To be able to formulate additional conditions using rules we had to use SWRL. By using SWRL and Drools rule engine we demonstrated search for information by content and inference on gathered knowledge. Using this approach a new knowledge is created about the $\mathrm{MS}^{2} \mathrm{~N}$ e-service, i.e. it is inferred, by the application example, that $\mathrm{MS}^{2} \mathrm{~N}$ e-service satisfies transparency, participation and collaboration requirements, which makes $\mathrm{MS}^{2} \mathrm{~N}$ an Open (e)Government service.

Open Government ontology proposed in this paper is an important but only the initial step toward generic Open Government model based on Semantic Web technologies. In this paper we have indicated only one potential application, which is to infer if some eGovernment service possesses features required by Open eGovernment. Consequently, we foresee an investigation of the capacity of the present version of the ontology to serve other Open Government applications as a first future research step. In our best judgement, the next step to be performed in order to apply this model to a greater extent, is research that should lead to further development of other components of the Open Government ontology such as Open Data and Open Standards ontologies.

\section{References}

[1] Berners-Lee, T. Design Issues: LinkedData, URL:http://www.w3.org/DesignIssues/LinkedData.html, 2006

[2] Hinkelmann, K.; Thönssen, B.; Wolff, D. Ontologies for Egovernment. // Theory and Applications of Ontology: Computer Applications. (2010), pp. 429-462.

[3] Pulinat, B.; Roth, B. PM440 course at DePaul CDM: Collaboration in Government, URL: http://pm440.pbworks.com/w/page/30698681/Collaboration in Government, 2011

[4] OECD. Building an open and innovative Government for better policies and service delivery. // OECD Guiding Principles for Open and Inclusive Policy Making, Paris, 2010

[5] Seok Sang, R. Concepts and Features of Government 2.0 and 3.0 // The National Information Society Agency, 2008

[6] Francoli M.; What Makes Governments 'Open? // JeDEM. 3, 2(2011), pp. 152-165.

[7] Open government partnership official website, URL: http://www.opengovpartnership.org/

[8] The home of the U.S. Government's open data, URL: https://www.data.gov/, 2009

[9] Haklae, K. Overview of Open Data, Linked Data and Web Science, PhD. // slideshare.net, August 2012

[10] Sabol, T.; Furdik, K.; Mach, M. Employing Semantic Technologies for the Orchestration of Government Services. // Semantic Technologies for E-Government, ISBN: 978-3-642-03506-7, Springer, 2010
[11] Ontologies for e-Government, URL: http://oegov.org/, 2010

[12] Hodgson, R. Enabling Data Independence for Government Transparency. // oeGOV: Open Government through Semantic Web Technologies, 2009

[13] Barabucci, G.; Di Iorio, A.; Poggi, F. Legal datasets integration:keep it simple, keep it real. // Semantic Web Journal, 2013. DOI: 10.1145/2539150.2539180

[14] Savvas, I.; Bassiliades, N. A Process-Oriented OntologyBased Knowledge Management System for Facilitating Operational Procedures in Public Administration. // Expert Systems with Applications. 36, 3(2009), pp. 4467-4478. DOI: 10.1016/j.eswa.2008.05.022

[15] The e-Government services factory, URL: http://www.ontogov.com, 2013

[16] Apostolou, D.; Stojanovic, L.; Lobo, T. P.; Miro, J. C.; Papadakis, A. Configuring e-government services using ontologies. // IFIP. International Federation for Information Processing, Springer Boston, Vol. 189.

[17] Impact of eGovernment on Local Government Services, URL: http://www.terregov.eupm.net/, 2007

[18] Perez, M.; Labajo, S. An Innovative Semantic Based Solution for eGovernment Interoperability. // IST Africa, Maputo, Mozambique, 9-11 May, 2007

[19] Providing Integrated Public Services to Citizens at the National and Pan-European level with the use of Emerging Semantic Web Technologies, URL: http://en.wikipedia.org/ wiki/SemanticGov, 2009

[20] Levette, N. E-Government - Government Business Reengineering, Canadian Methodology. // Business Transformation Enablement Program (BTEP), 2007

[21] Wang, W.; De, S.; Cassar, G.; Moessner, K. Knowledge Representation in the Internet of Things: Semantic Modelling and its Applications. // Automatika. 54, (2013), pp. 388-400. DOI: 10.7305/automatika.54-4.414

[22] Open Government Standards, http://www.opengovstandards.org/

[23] MITA - The Malta Information Technology Agency: eGovernment Services Directory, version 5, URL: www.mygov.mt, 2011

[24] Machado, A. L.; Parentede Oliveira, J. M. DIGO: An Open Data. Architecture for e-Government. // $15^{\text {th }}$ IEEE International Enterprise Distributed Object Computing Conference, Helsinki, Finland, EDOCW 2011

[25] Tinholt, D. The Open Data Economy, Unlocking Economic Value by Opening Government and Public Data. // Capgemini Consulting, 2013

[26] Vitvar, T.; Peristeras, V.; Tarabanis, K. Semantic Technologies for E-Government: An Overview. // DOI 10.1007/978-3-642-03507-4_1, Springer-Verlag Berlin Heidelberg, 2010. DOI: 10.1007/978-3-642-03507-4_1

[27] Brown, A.; Fishenden, J.; Thompson, M. Balancing agility and efficiency: Open architecture and platforms in government. // Digitizing Government: Understanding and implementing new digital business models, 2014.

[28] Petrušić, D. Conceptual Model of Open Architecture for Open Government. // CIST, Kopaonik, Serbia, 2013, pp. 148-155.

[29] Jörg, B.; Jeffery, K.; Asserson, A.; Van Grootel, G.; Grabczewski, E. CERIF2006-1.1 Full Data Model (FDM), 2007

[30] Bittner, S.; Müller, A. Social networking tools and research information systems: Do they compete? // Webology. 8, 1(2011).

[31] Montenegrin Semantic Science Network - Naučna mreža, URL: http://www.naucnamreza.me, 2012

[32] IKS for Drupal, URL: http://semantic-cms.info/, 2009

[33] Interactive Knowledge Stack (IKS), URL: http://www.iksproject.eu/, 2009 
[34] Broersma, R. Jr. Hierarchical data models in Relational Databases, URL: http://www.slideshare.net/navicorevn/ hierarchical-data-models-in-relational-databases, 2013

[35] Kumar Rout, S. EAV data model, URL: http://www.slideshare.net/MindfireSolutions/eav-datamodel-concepts, 2014

[36] Dinua, V.; Nadkarnia, P. Guidelines for the Effective Use of Entity-Attribute-Value Modeling for Biomedical Databases. // Int J Med Inform. 76, 11-12(2007), pp. 769779. DOI: 10.1016/j.jjmedinf.2006.09.023

[37] Pavlič, L. Improving e-services adoption with ontologybased repository. // The $7^{\text {th }}$ International Conference on Information Technology and Applications (ICITA 2011), 2011, pp. 267-270.

[38] Vassilakis, C.; Lepouras, G. An Ontology for eGovernment Public Services. // Encyclopedia of Ecommerce, E-Government and Mobile commerce, 2006

[39] Šolić, K.; Jović, F.; Blažević, D. An approach to the assessment of potentially risky behavior of ICT systems' users. // Technical Gazette. 20, 2(2013), pp. 335-342

[40] Sharman, R.; Kishore, R.; Ramesh, R. Ontologies: A Handbook of Principles. // Concepts and Applications in Information Systems, Chapter 2, Springer (2006)

[41] Ministry of Science official website, Montenegro, URL: www.mna.gov.me, 2009

[42] Higher Education for Research and Innovation project HERIC official website, Ministry of Science, Montenegro, URL: www.heric.me, 2012

[43] O'Connor, M.; Knublauch, H.; Grosso, W.; Dean, M.; Tu, S.; Musen, M.; Grosof, B. Supporting Rule System Interoperability on the Semantic Web with SWRL. $/ / 4^{\text {th }}$ International Semantic Web Conference, ISWC 2005, Galway, Ireland, November 6-10, 2005. DOI: 10.1007/11574620_69

[44] ProtegeWiki, URL: http://protege.cim3.net/cgibin/wiki.pl?WikiHomePage, 2012

[45] Drools, URL: http://www.drools.org/, JBoss Project

[46] Plinere, D.; Borisov, A. SWRL: Rule Acquisition Using Ontology. // Scientific Journal of Riga Technical University. Computer Sciences. 40, 1(2010), pp. 117-122. DOI: 10.2478/v10143-010-0016-8

[47] Cregan, A.; Mocho, M.; Vrandečić, D.; Bechhofer, S. Pushing the limits of OWL, Rules and Protégé, OWLED '05Workshop onOWL: Experiences and Directions, Galway, Ireland November 11-12, 2005.

\title{
Authors' addresses
}

\section{M.Sc. Darko Petrušić, dipl. ing.}

Ministry of Science,

Rimski trg 46, 81000 Podgorica, Montenegro

E-mail: darko.petrusic@mna.gov.me; pdarko30@hotmail.com

\author{
Assistant Prof. dr. sc. Milan Segedinac, dipl. ing. \\ University of Novi Sad, \\ Faculty of Technical Sciences, \\ Trg Dositeja Obradovića 6, 21000, Novi Sad, Serbia \\ E-mail: milansegedinac@uns.ac.rs
}

Prof. dr. sc. Zora Konjović

University of Novi Sad,

Faculty of Technical Sciences,

Trg Dositeja Obradovića 6, 21000, Novi Sad, Serbia

E-mail: ftn_zora@uns.ac.rs 